\title{
Opioids and Migraine: Opioid Awareness and Frequency of Use among Turkish Migraineurs
}

\author{
*D. H. Ertem¹, C. I. Basarir ${ }^{1}$, G. Baran², N. Gonderten¹, F. Ilik ${ }^{3}$ \\ ${ }^{1}$ University of Health Sciences, Sisli Hamidiye Etfal Training and Research Hospital, Department of Neurology, \\ Halaskargazi Cad., Etfal Sk., Sisli, Istanbul 34371, Turkey \\ ${ }^{2}$ Bezmialem Vakif University, Faculty of Medicine, Department of Neurology, \\ Adnan Menderes Bulvarl (Vatan Cad.), Fatih, Istanbul 34093, Turkey \\ ${ }^{3}$ KTO Karatay University, Medicana Faculty of Medicine affiliated Konya Medicana Hospital, \\ Musalla Baglari, Gurz St. N. 1, Selcuklu, Konya 42060, Turkey
}

\begin{abstract}
Despite the inadequate evidence of efficacy and safety of opioid use for the treatment of migraine, it has been reported that patients with moderate to severe migraine headaches are prescribed opioids. Migraineurs may experience serious health impacts from opioids such as headache-related disability, psychiatric and cardiovascular comorbidities. The reduction of the risk of opioid abuse and prevention of an opioid epidemic are important public health challenges. The aim of this study was to assess the awareness of opioid therapy for migraine and the frequency of use among Turkish patients with episodic and chronic migraine. Materials and methods: consecutive migraine patients were enrolled in this cross-sectional study. A semi-structured questionnaire was developed and used by the researchers to assess the patients' awareness of an opioid treatment option and the frequency of use of opioids for migraine treatment. Results. One hundred two patients were enrolled, of which 72 had episodic migraine and 30 had chronic migraine. All subjects reported that they had not been offered or prescribed any kind of opioids by general practitioners and neurologists for their headache. Besides, only $7 \%$ of patients declared that they had heard of opioid treatment for migraine but they had never consulted their doctors about its effects. Conclusions. Our findings demonstrated that opioids were not preferred as an option for acute or preventive migraine treatment by Turkish migraineurs and their physicians. The reduction of opioid prescription will help to prevent the development of medication overuse and opiate-induced headaches and drug addiction.

Key words: opioid; migraine; headache; episodic migraine; chronic migraine; prescription; drug abuse; drug addiction; frequency of use
\end{abstract}

For citation: Ertem DH, Basarir CI, Baran G, Gonderten N, Ilik F. Opioids and migraine: frequency of use and opioid knowledge among turkish migraineurs. Bezopasnost' $i$ risk farmakoterapii = Safety and Risk of Pharmacotherapy. 2019;7(3):139-145. https://doi.org/10.30895/23127821-2019-7-3-139-145

*Corresponding author: Devrimsel Harika Ertem; hkaozhan@gmail.com

\section{Опиоиды и мигрень: частота употребления и информированность о применении опиоидов у турецких пациентов с мигренью}

\footnotetext{
*Д. Х. Эртем ${ }^{1}$, Дж. И. Басарир ${ }^{1}$, Г. Баран ${ }^{2}$, Н. Гендертен ${ }^{1}$, Ф. Илик ${ }^{3}$

${ }^{1}$ Медико-санитарный университет, Научно-исследовательский и подготовительный медицинский иентр Шишли Халидие Этфал, отделение неврологии, пр-т Халаскаргази, ул. Этффал, р-н Шишли, Сталбул, 34371, Туриия

${ }^{2} У$ ниерситет Безлиалел Вакиф, ледицинский факультет, отделение неврологии, б-р Аднан Мендерес (пр-т Ватан), р-н Фатих, Сталбул, 34093, Туриия

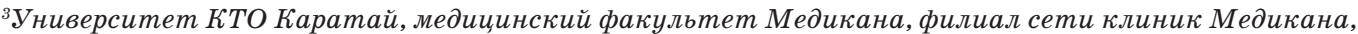
округ Мусалла Баглары, ул. Гюрз, д. 1, р-н Сельчуклу, Конья, 42060, Туриия
}

\begin{abstract}
Резюме. Несмотря на неочевидные доказательства эффективности и безопасности применения препаратов опиоидов для лечения мигрени, пациентам с головной болью от умеренной до тяжелой степени в качестве обезболивающей терапии могут быть назначены опиоиды. Однако при применении опиоидов возможно развитие таких серьезных нежелательных реакций, как инвалидизирующая головная боль, сопутствующие психиатрические и сердечнососудистые заболевания. Снижение риска злоупотребления опиоидами и предотвращение опиоидной эпидемии является актуальной задачей здравоохранения. Цель работы: оценка информированности пациентов на территории Турции о возможности назначения опиоидной терапии при мигрени и изучение частоты ее использования у пациентов с эпизодической
\end{abstract}


и хронической мигренью. Материалы и методы. В исследование были включены пациенты с рецидивирующей мигренью. Для оценки информированности пациентов о возможности использования опиоидов при мигрени была разработана и использована полуструктурированная анкета. Результаты. Исследование охватило 102 пациента, из них 72 - с эпизодической мигренью и 30 - с хронической. Все пациенты сообщили, что врачи общей практики и неврологи не предлагали и не назначали им опиоидные препараты при мигрени. Кроме того, только 7 \% пациентов заявили, что слышали о возможности терапии мигрени опиоидными препаратами, но они никогда не консультировались с лечащими врачами о нежелательных реакциях при назначении опиоидов. Выводы: результаты исследования свидетельствуют, что на территории Турции препараты опиоидов не были предпочтительным вариантом выбора для лечения приступов мигрени и их профилактики как для врачей, так и для пациентов. Ограничение назначения опиоидов способствует предотвращению развития чрезмерного употребления лекарств, наркомании, а также тяжелого побочного действия - головных болей, вызванных опиоидами.

Ключевые слова: опиоиды; мигрень; головная боль; эпизодическая мигрень; хроническая мигрень; назначение; злоупотребление лекарственными средствами; лекарственная зависимость; частота использования

Для цитирования: Эртем ДХ, Басарир ДжИ, Баран Г, Гендертен Н, Илик Ф. Опиоиды и мигрень: частота употребления и информированность о применении опиоидов у турецких пациентов с мигренью. Безопасность и риск фарлакотерапии. 2019;7(3):139-145. https://doi. org/10.30895/2312-7821-2019-7-3-139-145

*Контактное лицо: Девримсель Харика Эртем; hkaozhan@gmail.com

Migraine is one of the most frequent disabling neurological disorders with a high socioeconomic burden. Even though its pathophysiology has not been fully understood, it is known that the trigeminovascular system plays a significant role in the pathophysiology involving altered regulation and control of brainstem aminergic sensory modulatory systems, hypothalamic and thalamic structures [1, 2]. Pathophysiology and thus clinical characteristics may vary from person to person and between attacks in the same person [3]. Many analgesics have been used in the treatment of acute and chronic migraine. Abortive migraine therapy involves the use of such drugs as ergot derivatives, triptans, simple analgesics, and non-steroid anti-inflammatory drugs (NSAIDs), while migraine prophylaxis relies on such drugs as beta-blockers, calcium channel antagonists, anticonvulsants, anti-depressants, and onabotulinum toxin A [4]. Evidence of efficacy in acute migraine treatment in at least one placebo-controlled study has been reported for acetylsalicylic acid, paracetamol, and NSAIDs such as ibuprofen, naproxen, and metamizole [5]. However, the efficacy of opioids in acute migraine treatment has not been extensively investigated in randomized, double-blind, placebo-controlled clinical studies. Furthermore, optimal doses of opioids for migraine treatment have not been determined [4, 5].

Despite the inadequate evidence of efficacy and safety of opioid use for the treatment of migraine, it has been reported that patients with severe migraine headaches are prescribed opioids for pain relief. Although the benefits are not supported by any evidence-based study, the use of opioids in migraine patients in emergency departments is quite common in countries such as the United States and Canada [6, 7]. There have been studies evaluating opiophobia, prejudice against the use of opioid analgesics by patients and physicians, and the use of opioids for the management of cancer pain in Turkey $[8,9]$. However, the frequency of opi- oid use in Turkish migraineurs has not been well documented. The aim of this study was to assess the awareness of an opioid treatment option and the frequency of opioid use among Turkish patients with episodic and chronic migraine.

\section{MATERIALS AND METHODS}

\section{Study population and design}

The study protocol was approved by the Research Ethics Committee at the University of Health Sciences, Sisli Hamidiye Etfal Research and Training Hospital and carried out in accordance with the Declaration of Helsinki. Written informed consents were obtained from all the participants. In this cross-sectional, clinicbased study, patients older than 18 years with episodic migraine $(n=72)$ and chronic migraine $(n=30)$ who had been followed in a neurology outpatient clinic from August 2018 to December 2018 were recruited prospectively. The diagnosis of headache was made based on neurological examination, neuroimaging studies, and all the diagnoses were made according to The International Classification of Headache Disorders, 2018 (ICHD-3) [10].

Data on demographic and clinical characteristics such as age, gender, income, level of education, headache duration, headache severity (according to the numeric rating scale, 1 to 10), frequency and type of headaches in days, presence of medication overuse headache, and type of treatment were recorded. The results of all the subjects' physical and neurological examinations were normal. Patients who had been previously diagnosed by a professional with any other chronic health condition (i.e., neurological disorders other than migraine, endocrine disorders, mental illness, rheumatological disorders, cancer, etc.), patients with other types of headache disorders, as well as patients with comorbid headache disorders like migraine plus tension-type headache or other types of headache, were excluded. 
The researchers relied on their professional experience to develop a semi-structured questionnaire consisting of 4 questions related to the aim of this study. The survey was conducted to assess the patients' awareness of opioid treatment and the frequency of opioid use for migraine.

The questions are listed below:

1. Do you know any prescription opioids used for pain relief?

2. Do you know any prescription opioids used for migraine type headaches?

3. Would you consider using opioid therapy for your migraine headache if it was prescribed by your doctor?

4. Have you been prescribed opioids for your migraine headache?

\section{Statistical Analysis}

Statistical analysis was performed using SPSS Statistics for Windows, version 23.0 (SPSS Inc., Chicago, Ill., USA). Descriptive statistics (mean, standard deviation, and frequency) were used to assess the demographic and clinical characteristics. Student's $t$-test was used to compare the mean values obtained for the two patient groups. The Chi-square test was used for categorical variables. A $p$ value of $<0.05$ was considered to be statistically significant.

\section{RESULTS}

One hundred two patients were enrolled, of which 72 had episodic migraine and 30 had chronic migraine. The mean age of the patients was $38.22 \pm 9.06,79 \%$ of the patients were female. Twenty-three patients with chronic migraine had medication overuse headache $(\mathrm{MOH})$. There were no statistically significant differ- ences in age, gender, education level, marital status, income, duration of migraine between the episodic and chronic migraine groups (all $p$ values $>0.05$ ). Details of demographic and clinical characteristics of the subjects are given in Table 1.

The most commonly used analgesic for acute migraine attack treatment was paracetamol followed in order of frequency by non-steroidal anti-inflammatory drugs (NSAIDs), paracetamol and caffeine combination tablets, and triptans. In the chronic migraine group, beta blockers (propranolol and metoprolol) were the most commonly used drugs for preventative treatment of migraine followed in order of frequency by antiepileptic drugs (topiramate, sodium valproate and lamotrigine), antidepressants (amitriptyline and venlafaxine), botulinum toxin injections, anaesthetic blockade of the greater occipital nerve, and calcium channel blockers (flunarizine). Acute and preventive migraine treatments used by all the patients including the patients with chronic migraine are listed in Table 2.

According to the guidelines of the Turkish Ministry of Health on the prescription of opioids, both specialists and general practitioners are allowed to prescribe opioids. All the subjects who took part in the study reported that they had not been offered or prescribed any kind of opioids by general practitioners, emergency physicians and neurologists for their headache. Besides, only $8(7 \%)$ patients declared that they had heard about the use of opioids for the treatment of migraine but they had never consulted their doctors about this. Table 3 summarises the responses of episodic and chronic migraine patients to the questionnaire aimed at assessing the patients' awareness of an opioid treatment option and the frequency of opioid use for migraine treatment.

Table 1. Demographic and clinical characteristics of the patients with episodic and chronic migraine

Таблица 1. Демографические и клинические характеристики пациентов с эпизодической и хронической мигренью

\begin{tabular}{|c|c|c|c|}
\hline Characteristics of the patients & Episodic migraine & Chronic migraine & $P$ value \\
\hline Number & 72 & 30 & - \\
\hline Age (years) & $36.7 \pm 12.1$ & $42.8 \pm 11.4$ & $0.178 \%$ \\
\hline Gender (female/male) & $57 / 15$ & $23 / 7$ & $0.065 * *$ \\
\hline $\begin{array}{l}\text { Education } \\
\text { Primary school } \\
\text { High school } \\
\text { University }\end{array}$ & $\begin{array}{l}22 \\
24 \\
26\end{array}$ & $\begin{array}{c}11 \\
9 \\
10\end{array}$ & $0.719 * *$ \\
\hline $\begin{array}{l}\text { Income } \\
\text { None and minimum wage } \\
\text { More than minimum wage }\end{array}$ & $\begin{array}{l}38 \\
34 \\
\end{array}$ & $\begin{array}{l}18 \\
12 \\
\end{array}$ & $0.316 * *$ \\
\hline $\begin{array}{l}\text { Marital status } \\
\text { Single } \\
\text { Married }\end{array}$ & $\begin{array}{l}29 \\
43 \\
\end{array}$ & $\begin{array}{c}8 \\
22 \\
\end{array}$ & $0.172 * *$ \\
\hline Duration of headache (years) & $13.68 \pm 5.78$ & $14.5 \pm 6.22$ & $0.231 \%$ \\
\hline Number of headache days per month & $4.1 \pm 2.9$ & $21.2 \pm 4.8$ & $0.012 \%$ \\
\hline
\end{tabular}

Note. * Student's $t$-test was used for comparison of the mean values.

$* *$ The Chi-square test was used for categorical variables.

Прилечание. * Для сравнения средних величин использовали $t$-критерий Стьюдента.

** Для категориальных переменных использовали критерий хи-квадрат. 
Table 2. Acute and preventive migraine treatments used by the patients

Таблица 2. Препараты для купирования и профилактики приступов мигрени, используемые пациентами

\begin{tabular}{|c|c|c|c|}
\hline $\begin{array}{c}\text { Drugs for acute migraine attack } \\
\text { treatment }\end{array}$ & $\begin{array}{c}\text { All } \\
\text { patients* } \\
(n=102)\end{array}$ & $\begin{array}{c}\text { Drugs for preventive treatment of } \\
\text { migraine }\end{array}$ & $\begin{array}{c}\text { Patients } \\
\text { with chronic } \\
\text { migraine* } \\
(n=30)\end{array}$ \\
\hline Paracetamol & $54(53 \%)$ & $\begin{array}{c}\text { Beta-Adrenergic Blockers } \\
\text { - propranolol } \\
\text { - metoprolol } \\
\end{array}$ & $\begin{array}{c}10(33 \%) \\
8(26 \%) \\
2(7 \%) \\
\end{array}$ \\
\hline $\begin{array}{l}\text { Non-steroidal anti-inflammatory drugs } \\
\text { - ibuprofen } \\
\text { - etodolac } \\
\text { - flurbiprofen } \\
\text { - diclofenac-Na } \\
\text { - dexketoprofen } \\
\text { - others }\end{array}$ & $\begin{array}{l}42(41 \%) \\
10(10 \%) \\
8(7 \%) \\
8(7 \%) \\
5(5 \%) \\
5(5 \%) \\
6(5 \%)\end{array}$ & $\begin{array}{c}\text { Anti-Epileptic Drugs } \\
\text { - topiramate } \\
\text { - valproate } \\
\text { - lamotrigine } \\
\text { - others }\end{array}$ & $\begin{array}{l}8(26 \%) \\
4(13 \%) \\
2(6 \%) \\
1(3 \%) \\
1(3 \%)\end{array}$ \\
\hline $\begin{array}{l}\text { Combined analgesics } \\
\text { (paracetamol and caffeine) }\end{array}$ & $12(11 \%)$ & $\begin{array}{l}\text { Tricyclic antidepressants } \\
\text { - amitryptiline }\end{array}$ & $\begin{array}{l}6(20 \%) \\
6(20 \%)\end{array}$ \\
\hline \multirow{3}{*}{$\begin{array}{l}\text { Triptans } \\
\text { - eletriptan } \\
\text { - frovatriptan }\end{array}$} & \multirow{3}{*}{$\begin{array}{c}10(9 \%) \\
6(5 \%) \\
4(4 \%)\end{array}$} & Botulium toxin injection & $4(13 \%)$ \\
\hline & & Pericranial nerve blocks & $4(13 \%)$ \\
\hline & & $\begin{array}{l}\text { Calcium channel blockers } \\
\text { - flunarizine }\end{array}$ & $2(6 \%)$ \\
\hline
\end{tabular}

Note. $n$ - number of patients.

* Some patients had more than one acute and/or preventive treatment.

Примечание. $n$ - число пациентов.

* Некоторые пациенты использовали несколько препаратов для купирования и/или профилактики приступов мигрени.

Table 3. The responses of the patients with episodic and chronic migraine to the questionnaire on patients' awareness and use of opioids for their headache

Таблица 3. Ответы пациентов с эпизодической или хронической мигренью на вопросы анкеты об информированности об опиоидных препаратах и их использовании для лечения головной боли

\begin{tabular}{|l|c|c|}
\hline \multicolumn{1}{|c|}{ Questions } & $\begin{array}{c}\text { Patients with episodic } \\
\text { migraine } \\
(\boldsymbol{n}=\mathbf{7 2})\end{array}$ & $\begin{array}{c}\text { Patients with chronic } \\
\text { migraine } \\
(\boldsymbol{n}=\mathbf{3 0 )}\end{array}$ \\
\hline $\begin{array}{l}\text { Names of prescription opioids for pain relief known by } \\
\text { patients }\end{array}$ & $\begin{array}{c}\text { Morphine } \\
\text { Fentanyl transdermal } \\
\text { Tramadol }\end{array}$ & $\begin{array}{c}\text { Morphine } \\
\text { Fentanyl transdermal }\end{array}$ \\
\hline $\begin{array}{l}\text { The number of patients who knew/heard of migraine } \\
\text { treatment using opioids }\end{array}$ & $5(6 \%)$ & $2(6 \%)$ \\
\hline $\begin{array}{l}\text { The number of patients who might consider using } \\
\text { opioids if prescribed by doctors }\end{array}$ & $70(97 \%)$ & $30(100 \%)$ \\
\hline The number of patients who used opioids for migraine & None & None \\
\hline
\end{tabular}

Note. $n$ - number of patients.

Прилечание. $n$ - число пациентов.

\section{DISCUSSION}

The results of our study demonstrated that opioid therapy was not used as an option for acute or preventive migraine treatment by Turkish migraineurs. Furthermore, it was discovered that opioids were not prescribed and used by general practitioners, neurologists and emergency physicians. None of the patients had been prescribed opioids for their headache. This suggests that migraine chronicity had no connection with opioid use. Some studies report that both patients and physicians tend to avoid such drugs in the treatment of pain due to opiophobia in patients with chronic pain [8, $9,11]$. Opiophobia, defined as the irrational fear and prejudice against using opioids, is found among doctors because of the serious side effect profile of these drugs and the need for close follow-up, and among patients due to their fear of stigmatization and being addicted to the drug [9]. The research on opiophobia in Turkish patients is based on identification of opioid use for managing chronic cancer pain $[9,11,12]$. Although these stud- 
ies include a number of different research methods and approaches, it can be concluded that over half of the patients with chronic pain have doubts about taking opioids and they are afraid of using morphine for their pain. According to the responses to the questionnaire we developed, a remarkable number of patients with migraine reported that they might use opioids if their doctors advised them to do so. It can be said that opiophobia in migraineurs is less common than opiophobia in patients with cancer pain. This can be explained by different pain mechanisms of migraine and cancer pain, patients' clinical characteristics, comorbid disorders, cancer patients' fear, and severity of pain. In addition, this is the first study exploring the frequency of Turkish migraineurs' use of opioid analgesic drugs for migraine and headache relief. Our patients stated that they had not been informed about such a treatment alternative. The findings of the current study showed that chronicity of migraine, education level, gender, duration of headache, and medication overuse headache did not have any influence on the use of opioids for the acute and preventive (prophylactic) treatment of migraine.

Even though there is not enough evidence, opioids are recommended only as second or third-line therapy for migraine - following simple analgesics, NSAIDs and migraine-specific medications such as triptans for moderate to severe migraine pain, and they should be reserved for emergency department use or rescue medication with limited use [13]. It is reported that opioids are one of the most common medications for acute migraine treatment in the USA and Canada emergency rooms [6, 7]. However, opioid analgesics for migraine treatment are associated with more severe headacherelated disability, psychiatric and cardiovascular comorbidities, costs, and greater health-care resource utilization [14]. In a study by S.V. Tornabene et al., the researchers evaluated the use and timing of opioids for the treatment of migraine headaches in the emergency department. They reported that patients who received opioids for headache stayed in emergency rooms longer than patients who did not [15]. T.W. Ho et al investigated the effects of prior opioid use on rizatriptan efficacy. They demonstrated that prior opioid use was associated with lower triptan response in migraine attacks [16]. S.J. Tepper stated that acute opioid use results in failure of migraine prevention [17]. Moreover, opioids are responsible for migraine progression [14]. EFNS and NICE guidelines do not recommend opioids for acute treatment of migraine ${ }^{1}$ [5]. In this study, participants who visited the emergency department at least once for migraine attack treatment reported that they did not receive opioids.

Repeated morphine administration increases levels of calcitonin gene related peptide (CGRP) in the dorsal root ganglia in animal studies [18]. Upregulation of peripheral expression of CGRP in primary afferent neurons of trigeminal ganglion might be the most important reason for increasing levels of pro-nociceptive peptide involved in migraine pathogenesis triggering the frequency of attacks [19]. This mechanism might explain how opioids play a role in the chronification of migraine. It is well established that migraineurs are prone to developing chronic daily headaches namely chronic migraine or chronic tension-type headaches from opioid overuse [20, 21]. In addition, the overuse of opioids for the treatment of migraine is related to medication overuse headache. The use of opioids eight days a month is a risk factor of medication overuse headache [8]. Taking into account that the patients were not offered or prescribed opioid analgesics in the current study, we did not observe any association with chronification of migraine and medication overuse headache.

Awareness and motivation campaigns against excessive opioid use are carried out in written and visual media around the world. Several studies in developed countries have recently highlighted that opioid use is an important public health problem, and stated the necessity of limiting the use of opioids [22-24]. D.C. Buse et al. assessed opioid use and dependence and found that $16.6 \%$ of patients with chronic opioid use for migraine treatment met the dependence criteria and that these patients had more hospital admissions with more frequent recurrent complaints [25]. It is advisable that both patients and healthcare professionals should have realistic expectations of the intended benefits of treatment of chronic pain with opioids [26].

\section{CONCLUSION}

Opioid use is not a viable treatment option for Turkish patients with migraine. In order to raise awareness in our country, efforts are being made in many areas, including social media, to protect young people from such substances and addictions. At the same time, there are substance addiction treatment centres which provide support to individuals who are opioid addicts as a result of medical and non-medical use. As the present study is a single-centre study, its results are limited in scope and offer only a general reflection of the situation. However, our study was the first to evaluate both episodic and chronic migraine patients' awareness of opioid use in the treatment of migraine and reflected the perspectives of Turkish physicians and patients. Further studies of awareness of the general public and healthcare professionals about opioid use for the management of other headache types is warranted. It would be useful to understand the prevalence of opioid use for migraine treatment in other countries as well as views and opinions of professionals regarding the prescription practice.

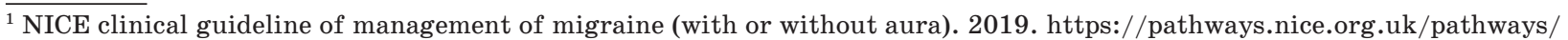
headaches/management-of-migraine-with-or-without-aura
} 
Acknowledgements. The study was performed without external funding. The authors wish to thank Mr. Mustafa Cem Ertem for statistical assistance.

Благодарности. Исследование проводилось без спонсорской поддержки. Авторы выражают благодарность господину Мустафе Джем Эртему за помощь в статистической обработке данных.
Conflict of interest. Authors declare no conflict of interest requiring disclosure in this article. All the authors have read and approved the paper.

Конфликт интересов. Авторы заявляют об отсутствии конфликта интересов, требующего раскрытия в данной статье. Все авторы прочитали и одобрили окончательный вариант рукописи.

\section{REFERENCES/ЛИTEPATУPA}

1. Goadsby PJ. Pathophysiology of migraine. Ann Indian Acad Neurol. 2012;15(Suppl 1):S15-22. https://doi.org/10.4103/0972-2327.99993

2. Goadsby PJ, Charbit AR, Andreou AP, Akerman S, Holland PR. Neurobiology of migraine. Neuroscience. $2009 ; 161(2): 327-41$. https://doi.org/10.1016/j.neuroscience.2009.03.019

3. Öztürk V. Acute treatment of migraine. Noro Psikiyatr Ars. 2013;50(Suppl 1):26-9. https://doi.org/10.4274/Npa.y7299

4. Antonaci F, Ghiotto N, Wu S, Pucci E, Costa A. Recent advances in migraine therapy. Springerplus. $2016 ; 5: 637$.

https://doi.org/10.1186/s40064-016-2211-8

5. Evers S, Áfra J, Frese A, Goadsby PJ, Linde M, May A, et al. EFNS guideline on the drug treatment of migraine - revised report of an EFNS task force. Eur J Neurol. 2009;16(9):968-81.

https://doi.org/10.1111/j.1468-1331.2009.02748.x

6. Friedman BW, Grosberg BM. Diagnosis and management of the primary headache disorders in the emergency department setting. Emerg Med Clin North Am. 2009;27(1):71-87. https://doi.org/10.1016/j.emc.2008.09.005

7. Colman I, Rothney A, Wright SC, Zilkalns B, Rowe BH. Use of narcotic analgesics in the emergency department treatment of migraine headache. Neurology. 2004;62(10):1695-700. https://doi. org/10.1212/01.wnl.0000127304.91605.ba

8. Colak D, Oguz A, Yazilitas D, Imamoglu IG, Altinbas M. Morphine: patient knowledge and attitudes in the central anatolia part of Turkey. Asian Pac J Cancer Prev. 2014;15(12):4983-8. https://doi.org/10.7314/apjcp.2014.15.12.4983

9. Şenel G, Oğuz G, Koçak N, Karaca Ş, Kaya M, Kadıogulları N. Opioid use and the management of cancer patient pain in palliative care clinic. Agri. 2016;28(4):171-6.

https://doi.org/10.5505/agri.2016.07830

10. Headache Classification Committee of the International Headache Society (IHS). The International Classification of Headache Disorders, 3rd edition (beta version). Cephalalgia. 2013;33(9):629-808. https://doi.org/10.1177/0333102413485658

11. Schiller M, Pyszora A, Graczyk M, Gajewska A, Krajnik M. Are the patients afraid of opioids? Pilot study of the patients with chronic cancer and nonmalignant pain. Advances in Palliative Medicine. 2007;6(4):121-4.
12. Oğuz GT, Şenel GÖ, Silbermann M. Palliative care unit in an oncology hospital in Turkey. Clin Oncol. 2016;1:1157.

13. Silberstein SD. Practice parameter: evidence-based guidelines for migraine headache (an evidencebased review): report of the Quality Standards Subcommittee of the American Academy of Neurology. Neurology. 2000;55(6):754-62.

https://doi.org/10.1212/wnl.55.6.754

14. Casucci G, Cevoli S. Controversies in migraine treatment: opioids should be avoided. Neurol Sci. 2013;34(Suppl 1):S125-8.

https://doi.org/10.1007/s10072-013-1395-8

15. Tornabene SV, Deutsch R, Davis DP, Chan TC, Vilke GM. Evaluating the use and timing of opioids for the treatment of migraine headaches in the emergency department. J Emerg Med. 2009;36(4):333-7. https://doi.org/10.1016/j.jemermed.2007.07.068

16. Ho TW, Rodgers A, Bigal ME. Impact of recent prior opioid use on rizatriptan efficacy. A post hoc pooled analysis. Headache. 2009;49(3):395-403. https://doi.org/10.1111/j.1526-4610.2009.01346.x

17. Tepper SJ. Opioids should not be used in migraine. Headache. 2012;52(s1):30-4. https://doi.org/10.1111/j.1526-4610.2012.02140.x

18. Ossipov MH, Lai J, King T, Vanderah TW, Porreca F. Underlying mechanisms of pronociceptive consequences of prolonged morphine exposure. Biopolymers. 2005;80(2-3):319-24. https://doi.org/10.1002/bip.20254

19. De Felice M, Ossipov MH, Porreca F. Persistent medication-induced neural adaptations, descending facilitation, and medication overuse headache. Curr Opin Neurol. 2011;24(3):193-6. https://doi.org/10.1097/WCO.0b013e328346af25

20.Wilkinson SM, Becker WJ, Heine JA. Opiate use to control bowel motility may induce chronic daily headache in patients with migraine. Headache. 2001;41(3):303-9. https://doi.org/10.1046/ j.1526-4610.2001.111006303.x

21. Bigal ME, Serrano D, Buse D, Scher A, Stewart WF, Lipton RB. Acute migraine medications and evolution from episodic to chronic migraine: a longitudinal population-based study. Headache. 2008;48(8):1157-68. https://doi.org/10.1111/j.1526-4610.2008.01217.x

22. Clark DJ, Schumacher MA. America's opioid epidemic: supply and demand considerations. Anesth Analg. 2017;125(5):1667-74. https://doi.org/10.1213/ANE.0000000000002388 
23. Huskamp HA, Busch AB, Souza J, UscherPines L, Rose S, Wilcock A, et al. How is telemedicine being used in opioid and other substance use disorder treatment? Health Aff (Millwood). 2018;37(12):1940-7.

https://doi.org/10.1377/hlthaff.2018.05134

24. Stannard C. Opioid prescribing in the UK: can we avert a public health disaster? Br J Pain. 2012;6(1):7-8. https://doi.org/10.1177/2049463712439131
25. Buse DC, Pearlman SH, Reed ML, Serrano D, Ng-Mak DS, Lipton RB. Opioid use and dependence among persons with migraine: results of the AMPP study. Headache. 2012;52(1):18-36.

https://doi.org/10.1111/j.1526-4610.2011.02050.x

26.Knaggs RD, Stannard C. Opioid prescribing: balancing overconsumption and undersupply. $\mathrm{Br} J$ Pain. 2017;11(1):5.

https://doi.org/10.1177/2049463716684055

\section{AUTHORS / OБ ABTOPAX}

Devrimsel Harika Ertem, MD. Деврилсель Харика Эртел, MD. ORCID: orcid.org/0000-0001-5309-1258

Celal Ilker Basarir, MD. Джелал Илькер Басарир, MD. ORCID: orcid.org/0000-0002-5044-9573

Gozde Baran, MD. Гезде Баран, MD. ORCID: orcid.org/0000-0002-6369-7218

Nihal Gonderten, MD. Нихал Гендертен, MD. ORCID: orcid.org/0000-0002-0739-1687

Faik Ilik, MD. Фаик Илик, MD. ORCID: orcid.org/0000-0001-5045-7082

Article was received 25 April 2019

Revised 12 July 2019

Accepted for publication 19 August 2019
Статья поступила 25.04.2019

После доработки 12.07.2019

Принята к печати 19.08.2019 